\title{
An automated passive haemagglutination technique suitable for the detection of hepatitis B virus antigen and antibody in blood donors
}

\author{
MARGARET NELSON ${ }^{1}$, ELIZABETH J. PHIPPS, PAMELA G. WATSON, \\ JACQUELINE R. WATTS, AND ROMAN ZWOLENSKI
}

From the NSW Red Cross Blood Transfusion Service and Technicon Equipment, Sydney, Australia

SYNOPSIS A method is described for preparing purified hepatitis B antigen (HB Ag) viral antigen without density gradient centrifugation. A method for sensitizing human group $\mathrm{O}$ red cells with this preparation is given, together with the technical details of an automated passive haemagglutination technique suitable for the mass screening of blood donors for $\mathrm{HB}$ virus and anti-HB antibody.

The history of the discovery and significance of hepatitis B antigen (HB Ag, Australia antigen, SH antigen, HAA) has been recorded in many comprehensive recent reviews (Cooksley, 1972; Fisher and Steiner, 1972; MacCallum, 1972; International Children's Centre, 1972; Sherlock, 1972; Wells and Fudenberg, 1972). Many studies have been made on the correlation between the transfusion of blood containing $\mathrm{HB}$ virus and subsequent hepatitis in the recipient (Chalmers, 1971; Gocke, 1972; Grady and Bennett, 1972; Maycock, 1972) and assessments have also been made of the relative infectivity of various blood fractions (Barker and Murray, 1972; Maycock, 1972). In order to decrease the incidence of post-transfusional hepatitis the screening of all blood donations became an obvious precaution, and the World Health Organization (1970) recommended that this should become standard practice.

Methods of detecting $\mathrm{HB} \mathrm{Ag}$ in serum or plasma were developed very rapidly. Gel diffusion and counterimmunoelectrophoretic methods were the first to come into general use, and have become progressively more sophisticated and sensitive; the development of complement fixation, latex particle agglutination, immune adherence, passive haemagglutination inhibition, radioimmunoassay, and electron microscopic techniques (see reviews by Taylor, 1972; Wells and Fudenberg, 1972) has provided increasing sensitivity in the detection of minute quantities of $\mathrm{HB} \mathrm{Ag}$. Evaluations of these techniques in terms of sensitivity and practicability for mass

\footnotetext{
${ }^{1}$ Address for reprints: Mrs Margaret Nelson, Biochemistry Department, NSW Red Cross Blood Transfusion Service, 1 York Street, Sydney NSW 2000, Australia

Received for publication 16 February 1973.
}

screening programmes have been made by many workers (Schober and Thomssen, 1972; Taylor, 1972; Wells and Fudenberg, 1972; Widman, 1972). The techniques in most common use for $\mathrm{HB} \mathrm{Ag}$ detection have been counterimmunoelectrophoresis and complement fixation, which combine the advantages of speed and reasonable sensitivity. For the detection of HB antibody (HB Ab), however, these techniques are somewhat insensitive (Barker and Peterson, 1972; Maddrey, Saito, Shulman, and Klatskin, 1972; Taylor, 1972).

It has been suggested that HB Ab may be useful in the prevention or amelioration of serum hepatitis (Krugman, Giles, and Hammond, 1971a; Prince, Szmuness, Woods, and Grady, 1971; Soulier, Blatix, Courouce, Benamon, Amouch, and Drouet, 1972; Alter, Holland, Schmidt, and Plotz, 1972). Screening of blood donors for HB Ab may be desirable to identify potential sources of immune gamma globulin. The only techniques so far found sufficiently sensitive for the detection of low levels of $\mathrm{HB} \mathrm{Ab}$ are passive haemagglutination and radioimmunoassay (Hollinger, Vorndam, and Dreesman, 1972; Maddrey et al, 1972; Taylor, 1972; Wells and Fudenberg, 1972).

In developing an automated passive haemagglutination test we wished to screen all donations for both $\mathrm{HB} \mathrm{Ag}$ and $\mathrm{HB} \mathrm{Ab}$ simultaneously, with a printout of results similar to the presentation of the results of blood grouping and antibody screening performed in this blood bank on a Technicon AutoAnalyzer. In this report we present themethods used in the preparation of pure $\mathrm{HB} \mathrm{Ag}$, the sensitization of human group $O$ red cells with this material, the technical details of the AutoAnalyzer manifold, 
and a preliminary evaluation of the automated passive haemagglutination method.

\section{Materials and Methods}

The methods now in use are reported below; experiments bearing on the selection of these methods appear in the next section.

\section{PURIFICATION OF HB ANTIGEN}

\section{Extraction of antigen from serum}

A full donation of blood is collected from a member of a panel of asymptomatic carriers of the HB virus. The blood is taken into a dry bottle. After cloting and retraction about $200 \mathrm{ml}$ of serum is aspirated into a further dry bottle, and $4 \mathrm{~g}$ of Aerosil 200 (Degussa, Germany) is added with mixing. The mixture is incubated for three hours at $37^{\circ}$. At the end of this period it is centrifuged at $1000 \mathrm{~g}$ for 15 minutes. The supernatant is discarded (for subsequent autoclaving) and the Aerosil is washed four times with $0.85 \% \mathrm{NaCl}$ (saline). The $\mathrm{HB} \mathrm{Ag}$ is eluted from the Aerosil with $100 \mathrm{ml}$ of $0.1 \mathrm{M}$ glycine/ $\mathrm{NaOH}$ buffer $\mathrm{pH} 9.5$ at $37^{\circ}$ to which is slowly added by syringe a further $100 \mathrm{ml}$ of this buffer containing $32 \mathrm{~g}$ of $\mathrm{NaCl}$. The final $\mathrm{NaCl}$ concentration is thus $16 \%$. After centrifugation at $1000 \mathrm{~g}$ for 15 minutes the supernatant is dialysed overnight against saline, and concentrated in the dialysis sacs by placing them in Carbowax 20000 (Union Carbide). The final volume of this partially purified material is about $10-20 \mathrm{ml}$ and it is stored at $-20^{\circ}$ until required. This method of extraction of the antigen follows closely that suggested by Brummelhuis, Duimel, and Krijnen (1971).

\section{Column fractionation}

Fractionation of the Aerosil extract is conducted on a $1.6 \mathrm{~cm} \times 100 \mathrm{~cm}$ column of Sepharose 4B (Pharmacia, Sweden) equilibrated in saline and run at room temperature. Between runs, columns are equilibrated in saline containing 1:100 000 merthiolate; the merthiolate is washed out with saline before any further fractionation is done. In this manner problems with bacterial contamination have been avoided. Approximately $5 \mathrm{ml}$ of the concentrated and semi-purified Aerosil extract is applied and eluted with saline at a flow rate of approximately $20 \mathrm{ml}$ per hour. The fractions collected ( $2 \mathrm{ml}$ each) are assessed for $\mathrm{HB} \mathrm{Ag}$ by a modified counterimmunoelectrophoretic method briefly described below. Fractions containing the antigen are pooled, concentrated in Carbowax 20000 as before to a final volume of approximately
$10 \mathrm{ml}$. This represents the volume from the original $200 \mathrm{ml}$ of donor serum.

\section{Pepsin treatment}

To this semi-purified HB Ag preparation is added $50 \mathrm{ml}$ of $0.02 \%$ pepsin (BDH) in $0.02 \mathrm{~N} \mathrm{HCl}$; the $\mathrm{pH}$ is adjusted to 2 with $0.4 \mathrm{~N} \mathrm{NaOH}$. The mixture is incubated for three hours at $37^{\circ}$; this treatment has been shown not to affect $\mathrm{HB} \mathrm{Ag}$ (Kim and Bissel, 1971). The mixture is then dialysed overnight against saline, concentrated to a final volume of approximately $5 \mathrm{ml}$ in Carbowax 20000 and reapplied to a Sepharose 4B column. The HB Ag content of each fraction is assessed as before and active fractions are collected into four consecutive pools. These four pools are filtered through an $0.22 \mu \mathrm{m}$ Millipore filter and each is independently assessed for the ability to sensitize red cells. Pools 2 and 3 are generally highly active in sensitization, and occasionally pool 1 could be included with them to provide the final antigen preparation. In this way each donor was found to be able to provide between 40 and $50 \mathrm{ml}$ of purified $\mathrm{Hb} \mathrm{Ag}$ preparation, with a protein concentration of between 30 and $60 \mu \mathrm{g}$ per ml measured by the method of Lowry, Rosebrough, Farr, and Randall (1951). This antigen preparation is stored in small aliquots at $-20^{\circ}$ until required.

\section{COUNTERIMMUNOELECTROPHORESIS}

The particular modification of this technique was developed in our laboratory two years ago and has served until now to screen all donors for HB Ag. It utilizes a discontinuous buffer system; grade $\mathbf{J}$ agar (The Davis Gelatine Company, Sydney) is used in a $1 \%$ solution in barbitone buffer of ionic strength 0.04 and $\mathrm{pH} 8.6$ coating six microscope slides held in immunoframes (Gelman) while the buffer is of ionic strength 0.08 . A pattern of 10 paired wells in each slide enables 59 samples to be screened in each frame, together with one control HB Ag-positive serum. The antibody well is 1.5 $\mathrm{mm}$ in diameter and the antigen well is $3 \mathrm{~mm}$ in diameter. A voltage of $7 \mathrm{v}$ per $\mathrm{cm}$ is placed across the ends of the frame with a maximal current of $20 \mathrm{~mA}$ per frame for approximately 30 minutes. The frames are subsequently washed in saline for 18 hours and for a further eight hours in tap water. The gels are dried and stained with Amidoschwartz containing $5 \%$ mercuric chloride (Boursnell, 1964). This staining procedure has been found to increase the sensitivity for antigen detection approximately fourfold (unpublished data).

The $\mathrm{HB} \mathrm{Ab}$ in use for all testing is a rabbit antiserum produced in this laboratory according to the following schedule. Each rabbit receives $2 \times 0.5$ 
$\mathrm{ml}$ of the $\mathrm{HB} \mathrm{Ag}$ preparation emulsified in an equal volume of Freund's complete adjuvant subcutaneously. Two weeks later a $1 \mathrm{ml}$ injection of $\mathrm{HB}$ $\mathrm{Ag}$ in saline is given intraperitoneally. One week later approximately $20 \mathrm{ml}$ of blood is taken from an ear vein and the rabbits are then re-injected intraperitoneally as before. The rabbits are subsequently bled at two-week intervals. The serum is absorbed with an equal volume of pooled sera from 100 normal donors. All antisera prepared in this way have been found specific for $\mathrm{HB} \mathrm{Ag}$ when tested against the NIH control HB antigen panel no. 2, and have given clear precipitin reactions with 30 of the 31 HB Ag-positive specimens claimed to be detectable by complement-fixation and immunoelectrophoretic methods.

\section{SENSITIZATION OF RED CELLS}

\section{Preparation of red cells}

Pooled citrated human group $\mathrm{O}$ red cells, one day old, are washed four times in saline. The packed cells are mixed with an equal volume of $0 \cdot 1 \%$ bromelin (Nutritional Biochemical Co, Cleveland) in phosphate-buffered saline of $\mathrm{pH} \mathbf{7 \cdot 2}$ and centrifuged at $800 \mathrm{~g}$ at room temperature for three minutes. They are then washed twice in saline and sensitized immediately.

\section{Chromic chloride}

One per cent chromic chloride in saline is aged at least two days before use (Langman, 1972). Aliquots are diluted 1:10 immediately before use. The stock solution keeps at room temperature for at least two months.

\section{Haemagglutination buffer}

The buffer used for resuspension of cells and for the dilution of $\mathrm{HB} \mathrm{Ag}$ and $\mathrm{HB} \mathrm{Ab}$ as controls is made as follows: $160 \mathrm{ml}$ saline; $28 \mathrm{ml} 0.15 \mathrm{M} \mathrm{Na}_{2} \mathrm{HPO}_{4}$; $12 \mathrm{ml} \mathrm{0} \cdot 15 \mathrm{M} \mathrm{KH} \mathrm{KH}_{2} \mathrm{PO}_{4} ; 4 \mathrm{ml} 25 \%$ human serum albumin (Commonwealth Serum Laboratories); $1 \mathrm{ml}$ Tween 20 diluted 1:100 (Technicon); 0.25 ml $10 \%$ polyvinylpyrrolidone (May and Baker).

\section{Sensitization}

Three volumes of $\mathrm{HB} \mathrm{Ag}$ preparation and 6 volumes of saline are heated to $98^{\circ}$ for one minute and cooled to room temperature. Two volumes of packed red cells and 1 volume of $0.1 \%$ chromic chloride are added and left with occasional shaking at room temperature for four to six minutes. The cells are centrifuged, washed twice with saline, and resuspended in haemagglutination buffer to a final concentration of $2.5 \%$. After sensitization the cells are stable for 24 hours if kept at $0-4^{\circ}$.
STORAGE OF SENSITIZED RED CELLS

A modification of the method of Chaplin and Mollison (1953) for deep freezing cells in glycerol has been found to preserve the sensitized cells without apparent loss of agglutinability. This method is as follows: 2 volumes of packed sensitized cells are mixed with 1 volume of $12 \%$ glycerol in $5 \%$ trisodium citrate, followed by the addition of 1 volume of $60 \%$ glycerol in $5 \%$ trisodium citrate. The cells are frozen and kept at $-20^{\circ}$. After thawing, the cells are dialysed against saline for at least 1.5 hours, or more conveniently overnight, then washed four times in saline before resuspension in haemagglutination buffer to a final concentration of $2.5 \%$.

\section{MICROTITRE ASSAYS}

These are performed in disposable V-bottomed microtitre trays (Linbro). Doubling dilutions in haemagglutination buffer are made with $0.025 \mathrm{ml}$ loops; $0.025 \mathrm{ml}$ of an appropriate dilution of rabbit antiserum (see Results) is added for $\mathrm{HB} \mathrm{Ag}$ determinations and finally $0.025 \mathrm{ml}$ of $0.5 \%$ sensitized cells in buffer is added. The plates are sealed with clear adhesive tape, mixed by inversion, and allowed to settle. Haemagglutination patterns are read after approximately two hours.

\section{AUTOMATION}

The system has been designed for a Technicon AutoAnalyzer, with a two-channel printout of the haemagglutination patterns onto paper. The manifold diagram for this machine is shown in figure 1 . The dilution of the antibody in the feed line for antigen detection is determined for each batch of sensitized cells. Generally 1:200 dilutions of the rabbit antisera described above have been used.

Control positive samples of both $\mathrm{HB} \mathrm{Ag}$ and $\mathrm{HB} \mathrm{Ab}$ are arranged at regular intervals around the turntable; the control antibody is a dilution of rabbit antiserum made as above; the control antigen positive sample is a 1:10 dilution of an $\mathrm{HB} \mathrm{Ag-}$ positive serum. The time from sample pick-up to appearance on the paper is 25 minutes, and 100 specimens can be sampled per hour.

\section{SPECIFICITY}

Samples apparently positive for either antigen or antibody are first tested with a suspension of sensitized cells $(2.5 \%)$ on a glass tile with or without $\mathrm{HB}$ Ab to ensure that the correct sample has been selected. The following tests for specificity of possible HB antibodies are made.

The serum or plasma is assayed for the presence of autoantibodies which may introduce false positive reactions. These tests, which are standard practice in this blood bank, include reactions in saline at 


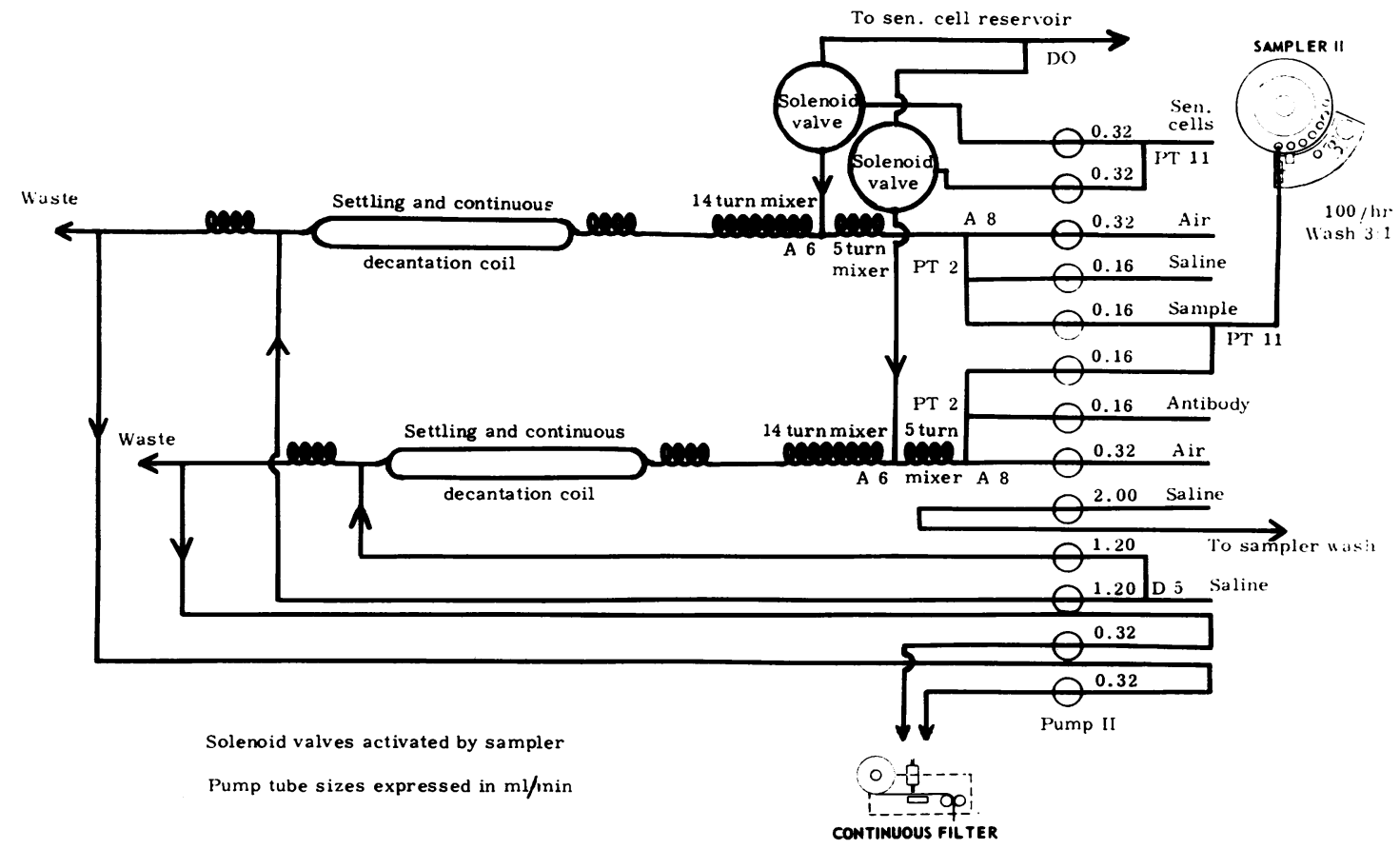

Fig 1 A diagrammatic representation of the AutoAnalyzer manifold.

room temperature against pooled red cells from two donors who are positive for all common red cell antigens; a two-stage papain test (15 minutes at $37^{\circ}$ ) for the detection of $R h$ antibodies; and an indirect Coombs test (one hour at $37^{\circ}$ ) conducted against pooled red cells from two donors who are positive for all red cell antigens except CDE. A suspected $\mathrm{HB} \mathrm{Ab}$ is tested with the bromelin-treated but unsensitized cells for signs of agglutination. All these tests being negative, the antibody is finally considered specific if the sensitized cells agglutinate maximally in the presence of at least two HB Ag-negative sera but is inhibited in the presence of at least two HB Ag-positive sera.

Suspected HB Ag-positive samples are examined by counterimmunoelectrophoresis; the serum or plasma is tested for inhibition of agglutination of the sensitized red cells in the presence of at least two different specific $\mathrm{HB}$ antibodies, including one human antibody.

\section{Results}

\section{HB ANTIGEN PREPARATION}

The major problem in devising an automated passive haemagglutination method for large scale screening of blood donors seemed to be a good supply of adequately pure $\mathrm{HB} \mathrm{Ag}$ for sensitization of the cells. In the absence of a high capacity ultracentrifuge the method of $\mathrm{HB} \mathrm{Ag}$ purification suggested by Brummelhuis et al (1971) seemed very promising. Table I shows the protein concentration and antigen yield (as measured by counterimmunoelectrophoresis) at various stages in the purification procedure. Absorption of antigen-positive serum with Aerosil resulted in considerable losses of antigen but yielded a product from which the bulk of serum proteins had been removed. Unlike Brummelhuis and his colleagues, however, we found that the material eluted from Sepharose 4B columns was still con-

\begin{tabular}{|c|c|c|c|}
\hline Material & Volume $(\mathrm{ml})$ & Protein $(\mathrm{mg} / \mathrm{ml})$ & Titre \\
\hline $\begin{array}{l}\text { Serum } \\
\text { Aerosil extract } \\
\text { Pepsin-treated }\end{array}$ & $\begin{array}{l}200 \\
10-20\end{array}$ & $\begin{array}{l}60-80 \\
70-80\end{array}$ & $6^{4-32}$ \\
\hline $\begin{array}{l}\text { preparation } \\
\text { Pure HB antigen } \\
\text { preparation }\end{array}$ & $\begin{array}{r}5-10 \\
40-50\end{array}$ & $\begin{array}{l}20-30 \\
30-60 \times 10^{-3}\end{array}$ & $\begin{array}{r}1024 \\
32-64\end{array}$ \\
\hline
\end{tabular}

Table I Range of protein concentration and the titres of $\mathrm{HB}$ antigen activity (measured by counterimmunoelectrophoresis) at various stages during the purification of the antigen 
taminated by alpha-globulins. The reports of the stability of $\mathrm{HB}$ Ag after various enzyme treatments (Kim, Spano, and Clark, 1971; Kim and Bissell, 1971) prompted us to try peptic digestion as a means of further purification. Fractionation of the digest on Sepharose 4B columns gave a final product, the purity of which is indicated by figure 2 . The HB Ag preparation shown had been concentrated some 10-fold by Carbowax 20000 and immunoelectrophoresis was performed using the concentrated material. The antisera used for development were rabbit $\mathrm{HB} \mathrm{Ab}$ and a commercial horse antihuman serum (Behringwerke).

Fig 2 Immunoelectrophoresis of a pure $H B$ antigen preparation concentrated 10 -fold.

a Developed with rabbit antiserum to $\mathrm{HB}$ antigen

b Developed with horse antihuman serum.

SENSITIZATION OF RED CELLS

In sensitization of the red cells the condition of the cells seemed to be of great importance. Aged cells were sensitized far more readily; bromelin-treated cells were found to give consistently better results. Table II shows the effect of bromelin treatment on the sensitization of citrated human group $O$ red cells of various ages, stored at room temperature or $4^{\circ}$ before being pooled and washed free of plasma. The reactions were performed on a glass tile and agglu-

\begin{tabular}{lllll}
\hline & Fresh Cells & $\begin{array}{l}\text { Cells Stored } \\
\text { One Day at }\end{array}$ & \multicolumn{1}{l}{$\begin{array}{l}\text { Cells Stored } \\
\text { Two Days at }\end{array}$} \\
\cline { 3 - 4 } & & $4^{\circ}$ & $18^{\circ}$ & $4^{\circ}$ \\
\hline $\begin{array}{l}\text { Untreated } \\
\text { Bromelin- } \\
\text { treated }\end{array}$ & + & + & + & ++ \\
\hline
\end{tabular}

Table II Effect of bromelin treatment on the degree of sensitization of pooled human group $O$ red cells of various ages and conditions of storage ${ }^{1}$

${ }^{1}$ Weak reactions are classified as \pm : strong and heavy agglutination is classified as ++++ . The cells were agglutinated on a glass tile by a 1:50 dilution of rabbit antiserum to $\mathrm{HB}$ antigen.

tination was assessed after 10 minutes of gentle rocking in the presence of a dilution of 1:50 rabbit $\mathrm{HB} \mathrm{Ab}$ in buffer. The reactions were graded according to a scale from \pm (fine and weak agglutination) to ++++ (heavy massive agglutination).

The effectiveness of sensitization of individual human $\mathrm{O}$ cells both with and without bromelin treatment is indicated in table III. The cells were one day old, and the reactions were assessed under the same conditions as those described above. It can be seen that variations in the agglutinability of sensitized cells from individual donors do occur, and the use of pooled cells has thus become standard practice.

\begin{tabular}{clllllll}
\hline & \multicolumn{6}{c}{ Individual Group } & \multicolumn{6}{c}{ Red Cells One Day Old } \\
\cline { 2 - 7 } & 1 & 2 & 3 & 4 & 5 & 6 \\
\hline $\begin{array}{l}\text { Untreated } \\
\text { Bromelin- }\end{array}$ & + & + & + & ++ & + & ++ \\
treated & ++ & ++ & ++ & +++ & ++ & +++ \\
\hline
\end{tabular}

Table III Effectiveness of sensitization of individual one-day-old citrated human group $O$ red cells with and without prior bromelin treatment ${ }^{1}$

${ }^{1}$ The cells were agglutinated on a glass tile by a $1: 50$ dilution of rabbit antiserum to $\mathrm{HB}$ antigen. The reactions were scored as indicated in table II.

It was found essential that the time of contact of cells, fresh or aged with bromelin, should be kept to a minimum. Cells incubated for as little as five minutes at $37^{\circ}$ in $0.1 \%$ bromelin rapidly became sticky during the sensitization procedure. The brief rinse with the bromelin solution proved to be most effective, and the cells remained discrete during a sensitization period of six minutes.

Reports of the effect of heat in reducing or eliminating the infectivity of HB virus (Berg, Björling, Berntsen, and Espmark, 1972; Cossart, 1972; Krugman, Giles, and Hammond, 1971b; Zuckerman, Taylor, Bird, and Russell, 1971) led us to examine the effects of various heat treatments on the purified HB Ag preparation. Table IV shows the results of such heat treatments on the subsequent ability of 


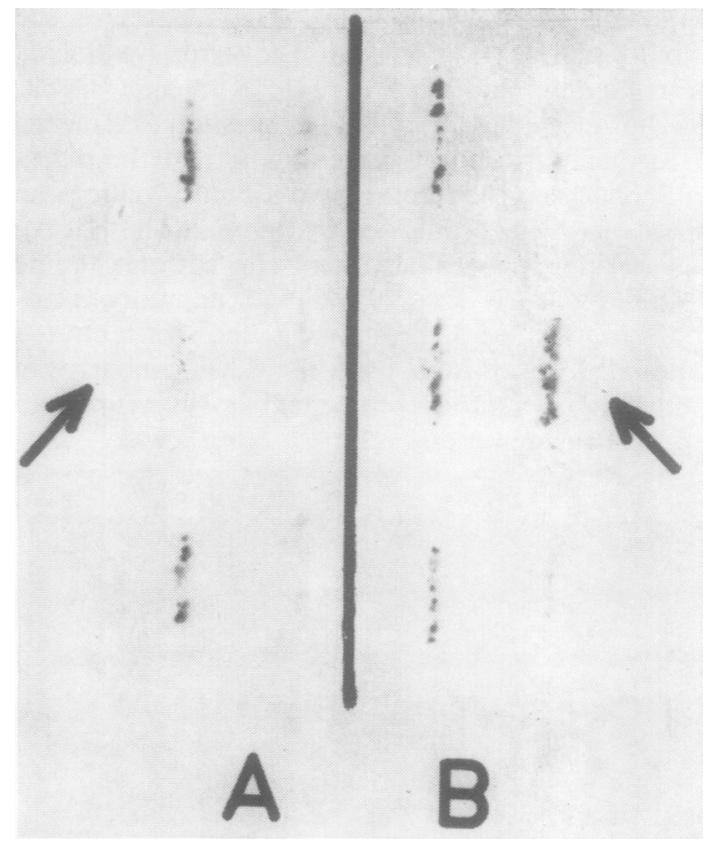




\begin{tabular}{|c|c|c|c|}
\hline & \multicolumn{3}{|l|}{ Titre } \\
\hline & \multirow[t]{2}{*}{ Electrophoresis } & \multicolumn{2}{|c|}{ Passive Haemagglutination } \\
\hline & & Automated & Microtitre \\
\hline \multicolumn{4}{|c|}{ Antigen } \\
\hline 1 & 2 & 8 & 8 \\
\hline 2 & 8 & 32 & 16 \\
\hline 3 & 64 & 64 & 64 \\
\hline 4 & 8 & 32 & 32 \\
\hline 5 & 16 & 16 & 16 \\
\hline 6 & 16 & 16 & 16 \\
\hline \multicolumn{4}{|c|}{ Antibody } \\
\hline 1 & 8 & $>512$ & 8192 \\
\hline 2 & 4 & 256 & 1024 \\
\hline 3 & 2 & 128 & 256 \\
\hline 4 & 4 & 128 & 2048 \\
\hline 5 & 4 & 256 & 1024 \\
\hline
\end{tabular}

Table V Comparison of the sensitivity of counterimmunoelectrophoresis and passive haemagglutination methods for the detection of $\mathrm{HB}$ antigen and $\mathrm{HB}$ antibody 1

${ }^{1}$ A dilution of $1: 200$ rabbit antiserum to $\mathrm{HB}$ antigen was used in the passive haemagglutination inhibition methods for antigen detection.

\begin{tabular}{|c|c|c|c|c|}
\hline & \multicolumn{4}{|c|}{ Passive Haemagglutination Inhibition } \\
\hline & \multicolumn{2}{|c|}{ Automated } & \multicolumn{2}{|c|}{ Microtitre } \\
\hline & \multicolumn{2}{|c|}{ Antibody Dilution } & \multicolumn{2}{|c|}{ Antibody Dilution } \\
\hline & $1: 100$ & $1: 200$ & $1: 100$ & $1: 200$ \\
\hline \multicolumn{5}{|c|}{ Antigen } \\
\hline 1 & 4 & 8 & 8 & 8 \\
\hline 2 & 8 & 32 & 16 & 16 \\
\hline 3 & 32 & 64 & 64 & 64 \\
\hline 4 & 16 & 16 & 16 & 16 \\
\hline 5 & 16 & 32 & 16 & 32 \\
\hline 6 & 8 & 16 & 16 & 16 \\
\hline
\end{tabular}

Table VI Influence of $H B$ antibody dilution on the sensitivity of passive haemagglutination inhibition methods for the detection of $H B$ antigen

occur, however, in testing for $\mathrm{HB} \mathrm{Ab}$; these nonspecific reactions appear to occur more readily when plasma rather than serum is tested. At present 4755 plasma samples have been screened and 35 apparent antibody-positive samples have been identified; of these 15 were non-specific $(43 \%$ of apparent positives). Of 1435 serum specimens tested, only one of 47 specimens causing agglutination of the sensitized cells was non-specific. None of the non-specific reactions was caused by the presence of common red cell antibodies, and further work remains to be done to determine the cause of these reactions.

\section{Discussion}

In trying to develop an automated method for the screening of blood donors for $\mathrm{HB}$ virus, passive 3 haemagglutination inhibition seemed to be the most promising technique because of its speed and sensitivity (Hollinger et al, 1972; Maddrey et al, 1972; Taylor, 1972; Vyas and Shulman, 1971). In this blood bank, blood grouping is performed by a Technicon AutoAnalyzer with a printout of the haemagglutination patterns onto paper; these results are then kept as a permanent record of each donation. The possibility of being able to present the HB status of every donor at each donation in such a manner was a great incentive, and the interest in the possible use of immune gamma-globulin for prophylactic or therapeutic use (Alter et al, 1972; Ginsberg, Conrad, Bancroft, Ling, and Overby, 1972; Krugman et al, 1971a; Prince et al, 1971) also made it desirable to test donor plasma for the presence of $\mathrm{HB} \mathrm{Ab}$. Electrophoretic methods of testing are grossly insensitive for antibody detection (Maddrey et al, 1972; Taylor, 1972; Wells and Fudenberg, 1972) and it has not been possible at this blood bank to test any donation for $\mathrm{HB} \mathrm{Ab}$ by the electrophoretic method because of the additional work involved. The ideal system then seemed to be an additional two channels on the AutoAnalyzer which would denote the HB status of the donor by a printout of patterns of red cell agglutination on paper. The problem of obtaining adequate supplies of an adequately pure HB antigen preparation without the use of an ultracentrifuge has now been overcome, and heat treatment of this antigen in a manner supposedly adequate for the destruction of infectivity (Krugman et al, 1971b) has meant an increased assurance in the handling of the sensitized cells by blood bank staff. The difficulties of sensitizing cells with the antigen seemed to be caused more by the condition of the red cell surface than by the nature of the antigen preparation, although the concentration and purity of the antigen was also critical. Rinsing the freshly washed red cells with $0.1 \%$ bromelin was found to be most effective in encouraging a maximal uptake of antigen by the cells; incubation with the enzyme for longer times caused the cells to clump during the sensitization step. The sensitized cells could be successfully stored by deep freezing at $-20^{\circ}$ in glycerol solution; bulk quantities can thus be prepared well in advance.

As expected, the sensitivity of the automated passive haemagglutination inhibition reaction for $\mathrm{HB} \mathrm{Ag}$ is dependent on the concentration of antibody used in admixing with the sensitized cells. The antibody used undiluted as a screening reagent in the counterimmunoelectrophoretic method for $\mathrm{HB} \mathrm{Ag}$ detection could be used in a dilution of $1: 200$ in the automated passive haemagglutination method; this dilution still caused the coarse clumping of the sensitized cells necessary for clear visibility on the 
print-out paper. The sensitivity for antigen detection was somewhat greater (up to four times with some sera) than that obtained with the standard counterelectrophoresis method. An added advantage is the considerable reduction in the quantity of $\mathrm{HB} \mathrm{Ab}$ used for screening compared with the electrophoretic method. The sensitivity for the detection of $\mathrm{HB} \mathrm{Ab}$ in donor plasma was found to be of the order of 32 times greater than that of the electrophoretic method, although it was two to four times less sensitive than passive haemagglutination assays conducted in microtitre trays.

There has been so far no problem with nonspecific reactions in terms of $\mathrm{HB} \mathrm{Ag}$ detection, but non-specific reactions occur in testing for $\mathrm{HB} A b$, especially when plasma rather than serum samples are being tested. The causes of the non-specific agglutination of sensitized cells are not yet known; common anti-red cell autoantibodies do not appear to be involved. Aged plasmas seen to give a higher proportion of false positive reactions, and further work must be done to determine what factor or factors are involved. Despite these false positive results for $\mathrm{Hb} \mathrm{Ab}$ they do not constitute a large proportion of plasmas tested $(0.3 \%)$, and tests for specificity are easily made within 10 to 15 minutes.

Sensitive and rapid screening of all donors for HB antigen and antibody can be carried out by the method described and the results are presented in such a way that a permanent record may be kept.

References

Alter, H. J., Holvand, P. V., Schmidt, P. J., and Plotz, P. H. (1972). Gamma-globulin for hepatitis-virus B: prevention or extension? Lancet, 1, 1110-1111.

Barker, L. F., and Murray, R. (1972). Relationship of virus dose to incubation time of clinical hepatitis and time of appearance of hepatitis-associated antigen. Amer. J. med. Sci., 263, 27-33.

Barker, L. F., and Peterson, M. R. (1972). Detection of hepatitisassociated antigen and antibody: comparison of methods and their application. Canad. med. Ass. J., 106, 486-492.

Berg, R., Björling, H., Berntsen, K., and Espmark, Å. (1972). Recovery of Australia antigen from human plasma products separated by a modified Cohn fractionation. Vox Sang. (Basel), 22, 1-13.

Boursnell, J. C. (1964). Personal communication.

Brummelhuis, H. G. J., Duimel, W. J. M., and Krijnen, H. W. (1971). Personal communication.

Chalmers, T., Chairman (1971). Control of hepatitis transmission by blood and its components. (Proceedings of the XXIVth Scientific Meeting of the Blood Research Institute, Boston, Mass.), Vox Sang. (Basel), 20, 440-462.

Chaplin, H., Jr., and Mollison, P. L. (1953). Improved storage of cells at $-20^{\circ} \mathrm{C}$. Lancet, 1, 215-218.

Cooksley, W. G. E. (1972). Australia antigen: a review with emphasis on its clinical relevance in Australia. Med.J. Aust., 2, 477-487.

Cossart, Y. E. (1972). Epidemiology of serum hepatitis. Brit. med. Bull., 28, 156-162.

Fisher, M. M., and Steiner, J. W., Editors (1972). Proceedings of the Canadian Hepatic Foundation Symposium on Viral Hepatitis. Canad. med. Ass. J., 106, 419-528.

Ginsberg, A. L., Conrad, M. E., Bancroft, W. H., Ling, C. M., and Overby, L. R. (1972). Prevention of endemic HAA-positive hepatitis with gamma-globulin: use of a simple radioimmunoassay to detect HAA. New Eng. J. Med., 286, 562-566.
Gocke, D. J. (1972). A prospective study of posttransfusion hepatitis. The role of Australia antigen. J. Amer. med. Ass., 219, 11651170.

Grady, G. F., and Bennett, A. J. E., Co-ordinators (1972). National transfusion hepatitis study. Risk of posttransfusion hepatitis in the United States: a prospective cooperative study. J. Amer. med. Ass., 220, 692-701.

Hollinger, F. B., Vorndam, V., and Dreesman, G. R. (1972). Assay of Australia antigen and antibody employing double-antibody and solid-phase radioimmunoassay techniques and comparison with the passive hemagglutination methods. J. Immunol., 107, 1099-1111.

International Children's Centre (1972). Seminar on Viral Hepatitis. Amer. J. Dis. Child., 123, 275-438.

Kim, C. Y., and Bissel, D. M. (1971). Stability of the lipid and protein of hepatitis-associated (Australia) antigen. J. infect. Dis., 123. 470-476.

Kim, C. Y., Spano, J., and Clark, G. E. (1971). Use of pepsintreated hepatitis-associated antigen in the production of precipitating antibody. J. infect. Dis., 124, 411-414.

Krugman, S., Giles, J. P., and Hammond, J. (1971a). Viral hepatitis type B (M S-2 strain). Prevention with specific hepatitis B immune serum globulin. J. Amer. med. Ass., 218, 1665-1670.

Krugman, S., Giles, J. P., and Hammond, J. (1971b). Viral hepatitis type B (MS-2 strain): studies on active immunization. J. Amer. med. Ass., 217. 41-45.

Langman, R. E. (1972). The use of erythrocytes sensitized with flagellar antigens from Salmonella for the assay of antibody and antibody-forming cells. J. Immunol. Methods, 2, 59-66.

Lowry, O. H., Rosebrough, N. J., Farr, A. L., and Randall, R. J. (1951). Protein measurement with the Folin phenol reagent. J. biol. Chem., 193, 265-275.

MacCallum, F. O., Editor (1972). Viral hepatitis. Brit. med. Bull., 28. 103-187.

Maddrey, W. C., Saito, S., Shulman, N. R., and Klatskin, G. (1972). Coincidental Australia antigenemia in primary biliary cirrhosis. Ann. intern. Med., 76, 705-709.

Maycock, W. d'A. (1972). Hepatitis in transfusion services. Brit. med. Bull., 28, 163-169.

Prince, A. M., Szmuness, W., Woods, K. R., and Grady, G. F. (1971). Antibody against serum hepatitis antigen: Prevalence and potential use as immune serum globulin in prevention of serum-hepatitis infections. New Engl. J. Med., 285, 933-938.

Schober, A., and Thomssen, R. (1972). Australia-Antikörper bei Normalpersonen und Serumhepatitis-Rekonvaleszenten. Dtsch. med. Wschr., 97, 939-942.

Sherlock, S. (1972). Long-incubation (virus B, HAA-associated) hepatitis. Gut, 13, 297-307.

Soulier, J. P., Blatix, C., Courouce, A. M., Benamon, D., Amouch, P., and Drouet, J. (1972). Prevention of virus B hepatitis (SH hepatitis). Amer. J. Dis. Child., 123, 429-434.

Taylor, P. E. (1972). Laboratory tests for Australia (hepatitisassociated) antigen and antibody. Brit. med. Bull., 28, 138-141.

Vyas, G. N., and Shulman, N. R. (1970). Hemagglutination assay for antigen and antibody associated with viral hepatitis. Science, 170, 332-333.

Wells, J. V., and Fudenberg, H. H. (1972). Australia antigen (hepatitis-associated antigen). Aust. N.Z. J. Med., 2, 278-291.

Widman, F. K. (1972). The Australia antigen: where do we stand? Postgrad. Med., 51 (1), 257-260.

World Health Organization (1970). Viral hepatitis and tests for the Australia (hepatitis-associated) antigen and antibody. Bull. Wld Hlth Org., 42 (1), 957-992.

Zuckerman, A. J., Taylor, P. E., Bird, R. G., and Russell, S. M. (1971). The Australia (hepatitis associated) antigen in fibrinogen and other fractions of human plasma. J. clin. Path., 24, 2-7.

\section{Addendum}

Since submission of this manuscript, it has been found that at a 'room temperature' of more than $25^{\circ}$ sensitization of red cells with $\mathrm{HB} \mathrm{Ag}$ is unsatisfactory. In these conditions cooling of the mixture or of the room to $20-25^{\circ}$ is necessary. 